\title{
An Ẽthos against Scarcity: Sketching an Ethic of Care and Dike for Late Modernity
}

\author{
Abstract \\ The "ethotic turn" in contemporary political thought is yet to theorize the sort of \\ ethos which is pertinent to the challenge of natural resources scarcity. This essay \\ seeks to address this gap and has therefore two aims: first, to offer an \\ understanding of ethos as mode of dwelling on the world; second, to sketch a \\ particular appearance of this dwelling, one that invokes care for human affairs, \\ but also the disposition to pursue justice, which is here affirmed as dike. An ethic \\ that is informed by these two elements, care and dike, disposes us to address \\ contemporary problems such as natural resources scarcity by urging us to think \\ of the current state of affairs not in order to manage it, but to re-arrange it \\ towards a more just direction. Heidegger's ontological scrutiny into "original \\ ethics" proves pertinent to the task undertaken in the essay. We are human, \\ "dwellers," because we care to achieve a more just, that is less hubristic, re- \\ arrangement of the "scheme of things."
}

Author's Bio

Sophia Hatzisavvidou earned a PhD in Political Theory from Swansea University, Wales, UK. She teaches political theory and rhetoric at the Department of Politics, Goldsmiths, University of London. She is currently working on a book project about the interplay between ethos and practical reason. She has previously published on non-violent forms of political engagement and on the rhetoric of social movements, whereas she is especially interested in alternative visions to neoliberal capitalism. Email:

\section{s.chatzisavvidou@gold.ac.uk}

Contact details: Department of Politics, Goldsmiths, University of London, New Cross, London, SE14 6NW, UK. Phone: +44 7857102245.

Introduction 
How are we disposed to the problem of natural resources scarcity that we face today and to the fact that certain natural sources remain unused, whereas the exploitation of others puts further strain on the already degraded biosphere? The scarcity of natural resources not only imposes a series of ecological issues on us; it also challenges democracy as organizational system and way of life, because it increases inequality, conflict, authoritarianism, and repression (Fisterbusch 2002, 93). One way to address this predicament would be the re-appropriation of our relation with the biosphere by ceasing to see it as a limitless source of extraction and consumption. This essay suggests that a certain part of this solution takes place on the domain of sensibilities, of what can be called the terrain of the ethotic. The overarching argument of the essay is that a certain ethos urges us to critically engage with ecological scarcity and to seek a more just rearrangement of the "scheme of things" in order to address the boundlessness of resources. In case that such a sensibility is absent, probably it is time to start thinking about the possibility of forging such an ethic, so as to attain a less uneven and indeed more balanced allocation of scarce resources.

My argument is organized around the following lines. First, I briefly consider the place of the concept "ēthos" in contemporary political thought and I claim that we lack a theoretical formulation of the ethic that is manifested in addressing the problem of scarcity of natural resources. Next I excavate the original meaning of ethos as habitat, as fixed abode, and I discuss how, despite being antithetical to the fluid and open character of late modern democracy, it proves pertinent to my task. I turn to Heidegger's ontological scrutiny into "original ethics" to sustain this claim. My next step is to demonstrate how Heidegger, through the early philosopher Heraclitus, helps us to overcome the narrow, restrictive topological understanding of ethos and affirm it as a process of dwelling. Through Heidegger (and Heraclitus) I reach the conclusion that ethos is the particular dwelling in the world, whereby one engages world affairs - affairs that concern human beings - with care. Finally, I enunciate a particular manifestation of èthos-as-dwelling, one that again draws on Heidegger, albeit contesting and expanding him. 
That said, although I join Heidegger in affirming etthos as a mode of relating one's self to the world in a way that is infused with care, I find that an ethic of care alone is inadequate when at stake is the formation of democratic responses to challenges such as that of resources scarcity. After all, Heidegger insists that in order to address complex problems we need to think hard on themand care hardly qualifies as such a way of thinking. If care is to inform an ethic that is pertinent to both the issues of scarcity and democracy, I propose, it needs to be amalgamated with a form of justice. I find that the virtue that ancient Greeks called dike, an ambiguous concept that refers to balance in order to avoid hubris, is pertinent here. An ethic infused with both care and dike corresponds to the urgency to address problems that emerge in "the common world," such as the pressing problem of natural resources scarcity.1

It is not only for his investigations into original ethics and his elaborations on dwelling and care that Heidegger is pertinent to the task undertaken in this essay. His critique of modernity's attitude towards nature, its transformation into "standing reserve" or "resource" (Bestand) which supplies "energy that can be extracted and stored as such" also informs much of the argument articulated here (Heidegger 1977a, 14). Yet, rather than completely abandoning the idea that nature and human beings can co-exist without the latter exploiting the former to the degree of extinction or disaster, I wish to try and enunciate the idea that indeed it is possible to achieve strong reciprocal relations among them within the "scheme of things" in which these two components participate. After all, modern wind turbines, unlike Heidegger's traditional windmills, may transform and store energy, yet they are one of our best alternatives to over-reliance on fossil fuels. The use of such sources is not immune to Heidegger's critique, but still it is sign of a much needed care for nature.

Demonstration of care is part and parcel of humanitas, the essence of being human. By attending to humanitas I do not presuppose human beings' superiority over all organic and inorganic life; neither do I imply that acting politically is a capacity exclusive to human beings.2 My purpose of visiting the idea of humanitas, rather, is to demonstrate how the human, as contrasted with the 
inhumane, is inextricably linked to care for the world. So is dike, a particular form of justice associated with balance. To be politically qua human is to dwell, to care for the world and to seek to reinforce dike in the "scheme of things." In other words, to dwell in the world politically is to care for and engage with world affairs in a responsive way, that is by endeavoring to forge a just, more balanced, less exploitative and less hubristic re-arrangement of things.3

\section{Defining Ēthos, Addressing Scarcity}

If there is something distinct about contemporary democratic politics compared to, say, the Athenian polis, the Roman res publica, or even democratic politics in the 19th century, this is the ever-growing pressure for a more just arrangement of human affairs, along with an expansion of means through and occasions on which this pressure is expressed. Articulated as demands for a fairer distribution of wealth and resources between different social and ethnic constituents, for a "greener" engagement with the natural environment or for a more charitable attitude towards thereligious, social, sexual—different, calls for justice are stronger, more frequent and multifarious than ever. We respond to different degrees and ways to these pressures, becoming attached to diverse claims and adopting various means to forward or address them. Such attachment does not necessarily entail loyalty to a party program or a strong organized form of participation. Political engagement takes different forms, from a single act that comes to disturb established perceptions to a movement that provides fleeting opportunities for participation. 4 There is a quality of fluidity and openness that characterizes democratic politics today, traits that render it not only flexible but fragile as well: democracy is under continuous reconsideration and redefinition, as well as subject to appropriation by all sorts of political groups. This ambiguity of democracy complicates, yet also underpins, the task of defining the dispositions that may infuse the fluid political reality. 
Political theorists have responded constructively to the challenge of defining such ethical sensibilities, invoking a burgeoning yet heterogenous body of literature, in which the concept "êthos" is placed at the centre of their analyses. Those who seek to theorize what can now be called the "ethotic" dimension of public life attend to the ways in which dispositional, along with affective, aesthetic, and intellectual factors infuse our political conduct, arguments, patterns of thought, and responses, without necessarily dictating them in any direct way. Thinkers of the ethotic turn affirm the interconnected participation of moral principles, ethical dispositions, corporeal reactions and rational functions in the formation of political judgments (e.g. Connolly 1995; 1999; 2002; 2005; Mouffe 1992; 1997; Norval 2007; White 2009). One of the virtues of an ethosapproach to the study of public life is that it enables us to defend democratic principles "in a contextualist manner, as being constitutive of our form of life," and not as being grounded on "something supposedly safer" (Mouffe 1996, 5). We need to know about ēthos, because this knowledge deepens our understanding of the intertwined character of the different layers of political enactment through judgment, identification and activism. To use the words of one of the pioneers of this turn, today "the issue of ethos in unavoidable" (Connolly 2008, 246).

Yet, the meaning of the concept of etthos per se as pertinent to public issues has not been scrutinized in depth. That said, even though theorists of the ethotic offer compelling accounts of what sort of èthos infuses demotic life, they usually employ the term without further elaboration. In addition, it is mainly issues of identity, difference, participation and citizenship that attract the interest of those who attend to èthos. Stephen White, for example, who enunciates an "ēthos of late modern citizenship," uses the term to refer to "a distinctive spirit" or affirmative ways in which we can engage more reflectively the distinctive challenges of modern life" (White 2009, 2). One encounters similar manifestations of the term in other works of political theorists, as for example Mouffe's “ēthos of democratic citizenship," Norval's "aversive èthos," and Young's "ēthos of 
differentiated solidarity." Despite their eloquent uses of the term, these thinkers do not analyze the very meaning of "êthos".

At the same time, challenges emerging from the environmental crisis are not addressed in the literature of the ethotic turn. An exception is Connolly, who suggests that ethos is better to be understood as "a set of contending dispositions" (Connolly 2008, 246). His later work demonstrates a developing interest in the interplay between human and nonhuman systems and seeks to offer, among other things, an understanding of the sort of ethos that could infuse a militant yet democratic response to the challenges imposed by climate change (Connolly 2011; 2013). Nonetheless, the problem of natural resources scarcity is yet to captivate the interest of political theorists of the ethotic turn, despite the fact that ethos is pertinent to the effort to form non-authoritarian responses to this problem. This is the gap that the present article addresses.

The demand to address scarcity is one of the issues that underlie pressures for justice in late modernity. Although it is economic scarcity that attracts the greatest interest of social and political thinkers, other forms of scarcity also invoke concern and activism. Biophysical scarcity, that is shortage of natural and material resources, such as land, water and fossil hydrocarbons, becomes the source of conflict, dispute, economic pressure and stress. This ecological scarcity indicates the need to adjust human activity to the actual physical realities of the biosphere. At the same time, though, scarcity of immaterial sources, such as time and willpower, imposes limitations on the human capacity to address the ecological scarcity and even hinder commitment to this task. To further complicate things, there is much disagreement over the sources of the problem. Consider the case of water scarcity. The United Nations Development Programme (UNDP) report on the global water crisis frames the problem as one of shortage of water supply, arguing that it is "poverty, inequality and unequal power relationships, as well as flawed water management policies that exacerbate scarcity" (UNDP 2006). Yet, the factuality of the problem, the fact that humanity is running out of water, as well as fossil fuels, points to the need to address it, even though we may disagree on the 
causes or the timescale of this shortage. It is not that ethos provides a solution to the problem. However, a response to it may begin or be underpinned by an etthos such as the one attempted to be sketched here.

To suggest that a specific èthos dictates, guides or underlies our responses to the exigencies of common life, such as growing scarcity, sounds, in the first instance, paradoxical. A brief genealogy of the term illuminates this claim and reveals that, as Reynolds observes, etthos "shifts and changes over time, across texts, and around competing spaces" $(1993,326)$. Ëthos ( $\eta \theta 0 \varsigma$ in Greek) echoes back into the late archaic years when, at least initially, the term is most commonly used in plural, as èthea. More specifically, it is Homer who uses it to refer to customary places of animals, such as stalls, and therefore to specify the places most appropriate to them in contrast to nomes, the pastures, which are characterized as fields of freedom (Homer 1977, 157; 2002, 271). The Homeric èthea are the restricted topoi of safety and return for the domestic animals; in this sense, etthos is associated with domestication and predictable behavior. With Hesiod there is a double shift in the meaning of the term, which now denotes human abodes but also the behavior of mortals and immortals. In Works and Days the èthea are places of association and co-existence such as haunts, towns, territories and homelands (Hesiod 2008, 41, 43, 52). But in the same text the term is introduced in its singular form to denote one's character and manners, which not only are not inborn but can, and indeed must,be taught $(5,39,57-8)$. This dual use of the term is passed on to the classical age, when the historian Herodotus alludes to it to refer to the native land or homeland of a people, but also to the manners of life, the customs or social practices that are common to them

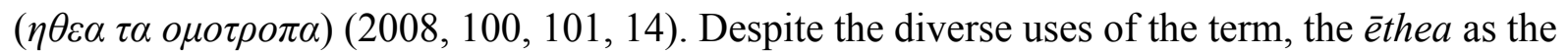
dwelling place, as the set of one's most characterizing traits, or as the customs common to a people, are associated with what can be seen as normal, ordinary and predictable. Ethos is the topos where one dwells, not only physically but also mentally and spiritually. 
How would this topological understanding of ethos-as-topos chime with the openness and fluidity of contemporary democracy? Following the logic of the original term, to suggest that a certain êthos underpins a particular political society is to make the case for a specific, fixed identity or set of traits shared among the members of this community. It is also to suggest that, because of this fixity, their political judgments, choices and behavior are predetermined and therefore predictable. Finally, it is to suggest that forthcoming demands, challenges and conflicts can be resolved by pertaining to this already established bond or code of conduct. In other words, the idea of ethos-as-topos is bound to the idea that political action can be circumscribed, that there is a way of being that corresponds to the political life of a particular community. But in conditions of plurality, fluidity and openness, such as those that mark contemporary demotic life, political identification shifts and changes. Ēthos-as-topos sounds not only irrelevant but even antithetical a term to associate with democracy.

Nonetheless, the idea of ethos-as-topos can provide the background to the type of ethos that I want to suggest here. It also forms the starting point of Heidegger's elaborations on èthos. To be sure, any effort to draw a democratic sense of èthos from Heidegger seems equally paradoxical, given the political undersides of his writings (Farias 1989; Habermas 1992; Wolin 1990). Even though it is not my intent to twist Heidegger in order to make him appear as if he embraces political ideas that he evidently did not, I believe that it is possible to read some of his ideas not in order to apply them to politics but to exploit them in order to start thinking on political issues. That said, in the remaining of this paper I would like to suggest that, drawing on the concept of ethos-as-topos, we can affirm ethos as the practice of dwelling that carries an element of care in it. Heidegger proves relevant to the task of scrutinizing the meaning of etthos, because thinking with Heidegger, we can avoid the restrictive connotations of dwelling as abode, or fixed place, and grasp etthos as a mode of $d$ welling, of associating ourselves with the world. Thus understood, association with the world may occasionally demand staying attuned to its justices and injustices and forming critical 
responses to them. In a sense, we are $d w e l l e r s$, that is we demonstrate an ethos-as-dwelling, because of our ability to care for the "scheme of things;" and because we do so while pondering over it and seeking to re-arrange it towards a more just, that is a more balanced, direction. I find that such an ethic of care and making-justice towards the current and the to-come can infuse demotic life, and that it corresponds to the flux of the political experience in late modernity, particularly its aspects that relate to scarcity.

\section{Heidegger's Daimons: Humanitas and Ēthos}

Although it is in his later philosophical investigations that Heidegger develops a systematic account of etthos, the issue is not absent from his earlier works. In fact, as early as in his 1924 Marburg lectures, Heidegger offers an expanding reading of the classical understanding of ethos as the orator's character. In these lectures, Heidegger takes on the fundamental Aristotelian idea that human beings exist in a community where they live miteinander, with one another, because their ability to use language enables them to do so. Reading closely Aristotle, Heidegger explains that the way of living while being-with-one-another is itself a techne, an art, a knowing-a-way-around, which enables humans to open themselves to and deal with the world to which they are exposed. In Heidegger's words, “This standing-out [in being-with-one-another] of the human being, this

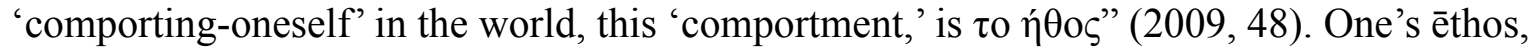
Heidegger suggests, is the art of exposing oneself to the occurrences of the world. Unsurprisingly, there is a certain degree of continuity between this statement and the approach that appears in Heidegger's later work; yet, in the latter he explicitly departs from the Aristotelian conception of ethos and seeks to advance a broader yet original interpretation of the archaic meaning of ethos-astopos. This latter is the focus of my discussion here. 
When in his Letter on Humanism (1946) Heidegger defies Sartre's claim that human nature cannot be defined in any objective way and inquires into man's essence, he does so not in order to restore meaning to the word "humanism," but in order to determine humanitas, what is to be human and not inhumane, "inhuman" (Heidegger 1977b, 224). At the same time, he also seeks to respond to the question regarding the place of ethics in his work, a task which for Heidegger entails avoiding the grounding of decisions over good and evil on metaphysics. To do so, Heidegger reflects on the relation between ethics and ontology by finding recourse to what he calls "original ethics"- that is ethics as related to the archaic concept ethos. Heidegger sees the urgency of the question concerning ethics in light of the human predicament, which in the Letter on Humanism he affirms as "the hidden perplexity of man [which] soars to immeasurable heights" not least due to man's attunement to technology, the rise of what Heidegger calls "technological man:" the man that "can be kept reliably on call only by gathering and ordering all his plans and activities in a way that corresponds to technology" (255). Heidegger's aim is to offer a response that avoids peremptory directives and rules of conduct on how one ought to live in a fitting manner. This takes him to pre-Socratic thought when, as he observes, physis was still implicit in the discussion of ethics and therefore the preservation of ethos was attained through attentiveness to the instinctive and visceral (256).

It is his search for "original ethics," then, that guides Heidegger to the early philosopher Heraclitus and one of his most famous yet ambiguous sayings: èthos anthrōpoi daimōn. Heidegger endeavors to interpret the fragment by breaking it into its components. He starts by defining êthos as "man's abode, dwelling place," straightforwardly referring back to the archaic concept of ethosas-topos (256). But at the same time Heidegger shifts emphasis from topos as space of delimitation and domestication to "dwelling place" as "the open region in which man dwells" (256). The element of openness that Heidegger inserts in the discussion points, I believe, to the potentiality of inhabiting the world in diverse ways, to the multiplicity of modes of identification and attachment available to individuals. Thinking with Heidegger, and expanding this short definition, I will 
enunciate an account of etthos that corresponds to the fragmentation and fluidity of contemporary political life.

To unravel this argument I suggest that we unpack Heidegger's interpretation of ethos, affirmed as rich terrain of occurrences. As he explains, etthos is the terrain of "the advent of what belongs to man in his essence" (256). Man's etthos is inextricably linked to his quality as human, as contrasted with inhuman. It is the open area where man welcomes, hosts and maintains "what pertains to [his] essence, and what in thus arriving resides in nearness to him" (257). As such, èthos is the territory where one's way to be qua human unfolds. Heidegger tells us that there is no prefixed truth or objective order that is knowledgable; the essence of being human does not lie neither in any preconceived image of man (e.g. Marx's social man, Aristotle's political man, etc.), nor in finding out how the world is organized and functions. Rather, the essence of being human lies in the way we think about the truth of Being. My reading of Heidegger suggests that he associates ethos with the intimate, with the ontologically pertinent to human essence in its most common and ordinary aspect. Nonetheless, he does not connect ordinariness with normalcy or mediocrity: our ordinary abode, the region where we host what pertains to our human essence at the same time welcomes the unexpected, what can appear to this open dwelling place and stir our interest. The key word that leads me towards this expanding elucidation is another obscure concept found in the saying under scrutiny: daimon.

Heidegger continues his inquiry in "original ethics" by recounting a story found in Aristotle, a story that helps him to interpret the meaning of the polyvalent term daimon. In this story Heraclitus (once again) is found by a companion of visitors at the stove trying to warm himself, a view that frustrates and disappoints the strangers who expect a more glorious and perhaps less miserable view of the famous thinker. However, the philosopher invites them to stay, using the words einai gar kai entautha theous: "here too the gods come to presence." Heidegger explains that 
even at "a common and insignificant place" such as a stove, one can expect to experience "the exceptional and rare and so the exciting"; one can expect to find his daimon (257).

Etymologically meaning the "one who distributes or assigns a portion," the term is used by Homer and other authors of this era synonymously with "god" or "divinity" (Kahn 1979, 261). It is in this sense that daimon is also one's destiny and fate. However, to have a daimon does not entail that one does not have control over one's own life; by contrast, it is the choices one makes and their consequences that define one's self. Credence in the existence of daimons does not imply belief in a transcendental function of the world. Indeed the Heraclitean god exists in the constant transformations and opposites of nature; it is immanent in the world (Kirk 1975, 166).5 The daimon, one might say, is used as an encompassing term to affirm the world and its function in its totality, without dividing it to humans and nonhumans, to divine and mortal powers. In Heraclitean terms, the world already is this bipolarity; the constituents of each bipolarity already belong to and define each other. Heidegger shares with Heraclitus an immanent understanding of the function of the world, at least in that he rejects "outfitting man with an immortal soul, the power of reason, or the character of a person" (Heidegger 1977b, 229). One is human not due to any intrinsic characteristic, but in so far as one ek-sists as dweller in the world, not in order to secure a place for oneself in it among any true order of things, but rather in order to participate in the re-arrangement of an ever-changing "scheme of things."

This investigation in the meaning of daimon is not irrelevant to Heidegger's efforts to ground his scrutiny of ethics in an immanent perception of the world, while at the same time embracing the holy without reducing it to a certain theism. The humanitas of Heidegger's man does not contradict the divinity of god. Heidegger appeals to daimon as the immanent power that underpins human affairs, the tangible truths that participate in the arrangement of human affairs. To find one's daimon is to meet the exciting in the most common place: Heidegger, I believe, suggests that man is human insofar as he takes care of human affairs. It is our "way to be" that defines our 
humanism; therefore, to be human, Heidegger explains, is to take care of what arrives to our nearness. The essence of humanitas lies in the way that man is and that man thinks of Being; of man as being in the world.

Heidegger's discussion of the human essence suggests that man qua human cannot exist segregated from the world; indeed, he becomes capable of understanding himself, "what" and "who" he is, only by interacting with what is in his proximity. Ëthos is one's territory, the place which "first yields the experience of something we can hold on to" (262). But rather than understanding this territory as a non-permeable place that one occupies and possesses, Heidegger invites us to affirm it as a terrain that one explores through a process of exchange with what "resides in nearness to him" (256). Hence the shift from êthos affirmed as restricted topos, to êthos as open terrain. Heidegger's ethos is closer to the archaic nomes.

By the end of his discussion, Heidegger interprets Heraclitus as saying: "The (familiar) abode for man is the open region for the presencing of god (the unfamiliar one)" (258). Even though the daimon denotes something that initially is unfamiliar, in the sense of the unknown, unpredictable and even antithetical to one's ordinary condition, it is still possible to acknowledge, explore and embrace it. It is by remaining open to different encounters and occurrences, by inviting and hosting them at one's most familiar and ordinary condition, that one comes to know the world and oneself. One's abode, that is one's êthos, does not need to denote an area already assigned to him, an established and permanent condition or set of actions and traits; it can be the starting point of reference from which one explores the world. Therefore, one's ethos does not remain fixed and predictable; through these explorations it is transformed and adjusted, becoming each time a new departure point that encompasses what has already been experienced. It is in this sense, of embracing both the familiar and one's daimon, that ethos is a "way of being," of accommodating oneself to the current and to that to-come (see also Nancy 2002, 78). It is the process that, in an instance, enables one's detachment from his accustomed circumstances, shifting abodes and 
exploring new ones; èthos enables one to become what one is. 6 In what follows, I would like to make this shift from topos to dwelling more explicit. I want to suggest, then, that ethos is a dynamic dwelling, a process of engaging with what appears to one's nearness. Heidegger is relevant here.

\section{Towards an Understanding of Ēthos-as-Dwelling}

Does this idea of ethos-as-dwelling, in the sense of dynamic process of engagement with the world, correspond to the exigencies of "the common world" in late modernity? I believe it does and the element of care that is folded in my understanding of dwelling is an essential starting point to address these exigencies. Heidegger proposes that man is specifically human - that is, not inhuman

—because he ponders over his role in the world while affirming that he is only one of the world's many constituencies, of what he schematically calls "the fourfold." To be infused with an êthos-ofdwelling, I argue, is to inhabit the world in a way that shows care for the affairs of the world, whereby care entails also critical engagement with the occurrences that, in Heideggerian terms, arrive in it. "Nearness," then, is not to be perceived as a call for local or localized democratic action, at least not exclusively. To engage with what appears to ones nearness is to care for "the fourfold," for the world in its totality, even though this care might be manifested on the occasion of local, small-scale actions, projects, and initiatives.

The expanding reading of Heidegger's account of èthos that I attempt here resonates with, and is reinforced by, his reflections on dwelling found in Building Dwelling Thinking (1971). In this essay Heidegger inquires into the essence of being human which, once again, he connects with the capacity of dwelling and thinking, but also with that of building, given that his concern in this essay is with a particular form of scarcity, namely post-war housing shortage. Heidegger asserts that in German the word "being" is etymologically already associated with and implicit in both building and dwelling - there is a continuity between the practice of building and that of dwelling and this 
relation of continuity is an essential part of being. However, this sequence has fallen silent, Heidegger argues. To build, he advocates, is to dwell, to be in a certain way, while "the manner in which we humans are on the earth is... dwelling. To be a human being means to be on the earth as a mortal. It means to dwell" $(1971,145)$. Dwelling is the very essence of being human, in line with what Heidegger has already suggested in his Letter on Humanism.

Nonetheless, in Building Dwelling Thinking Heidegger further advances his assertion of dwelling as the essence of being; he now clarifies that dwelling is a practice and more specifically an act of cherishing and protecting, preserving and caring for. The aspect of care folded in dwelling seems to be crucial, not least because to dwell is to remain at peace with the open and free abode in which things naturally are: it is to respect and preserve this space (147). More specifically, to dwell is to spare and preserve what Heidegger calls "the fourfold": the oneness of earth, the sky, mortals and divinities, each different but implicit in the other, while participating in a unity (148).7 Echoing again Heraclitus, who held a cosmological view according to which all is one yet ever-changing, Heidegger observes that everything — and so nature, human culture and belief systems - belongs to a single oneness. To dwell, then, is to affirm that to be human, and consequently to be mortal, is to be an integral part of the oneness of "the fourfold"; to be human is to be unable to live detached from “the fourfold.” Jeff Malpas advocates that dwelling as preserving entails one's ability to situate oneself to the question of being, of existing as human, and therefore the ability to embrace finitude and boundedness $(2007,277)$. One dwells where "one can feel the world's relationship," where one can affirm his multiple belongings, while embracing the fact that he cannot separate himself from the earth, sky, and values or truths of the human culture (Camus 2005, 13). One is human insofar as one remains responsive to the exigencies that mold his being on Earth.

To dwell while "letting things be" as espoused in Building Dwelling Thinking is not to exist in the world in a condition of inertia or negligence. Dwelling, instead, is the activity of preserving the world; it is a form of dynamic engagement with the world. To dwell is to remain, to stay in a 
place, and more distinctly to remain in peace with something, to accept it and so to spare it. This sparing is, according to Heidegger, the fundamental character that pervades dwelling in its whole range $(1971,147)$. Such a protection is not merely apathy, though; it is an activity. As Thiele argues "letting things be" is not to be understood in the sense of abandonment but in that of forming "dynamic worldly relationships, ones all the more dynamic because they are no longer constrained by the limitations of a subject/object dichotomy" $(1994,214)$. For Heidegger, this kind of dwelling is the ontological essence of human being. One is human because one is dweller, that is because one is able to dwell while preserving and sparing, while letting things be as they naturally are, and therefore while embracing and accepting one's place in "the fourfold." It is not only one's mortality and finitude that defines one's humanity, but also one's purpose to take care of world affairs.

In summary, I suggest that it is by bringing and reading together Heidegger's reflections on etthos and those on dwelling that we can fully appreciate the expanding interpretation of Heraclitus' fragment that Heidegger offers and so his contribution to the discussion on ēthos. In his early, Aristotelian, elaborations, Heidegger affirms èthos as comportment, as the technē of comporting oneself in the world. His later elaborations on dwelling help me to demonstrate that ethos-asdwelling is the techne of making oneself appear in the world: it is the techne of inhabiting the world. At the same time, it is the technē of relating with the world's other inhabitants, both human and non-human, and so a series of gestures that are characterized by openness and care that aim at sparing and preserving the world. As such, etthos-as-dwelling is a process that develops outwards, towards what man can see and know as the being that dwells in an open, fluid and permeable space. It is on the basis of man being dweller, and therefore his being capable of sparing and preserving a world of which he forms an integral part, that his humanitas is established. By turning to Heraclitus in searching for “original ethics," Heidegger embraces and expands the early thinker's view that one's etthos is not merely his character or morality, but a set of different constituents such as affects, behavior patterns, reactions, and identifications; it is one's "way to be." Thus conceived, our ethos 
forms and at the same time is formed by our actions and thoughts, our engagements with the world and our aspirations of it. It becomes our daimon in the sense that it guides us through our adventures in the world, albeit remaining sensitive to change in their pass.

Would an understanding of ethos in the Heideggerian/Heraclitean sense prove pertinent to the task of forming democratic responses to common problems in late modernity, such as scarcity? I suggest it can, in a way that does not reduce ethics to a set of binding codes of conduct and therefore in way that is less violent and more affirmative, not only because it invites co-existence with what surrounds us, but also because it calls for embracing change and reformation. It is because it corresponds to late modern fluidity that etthos-as-dwelling proves pertinent to the question of what sort of ethic infuses political life today. This ethic, I suggest, is one that combines the elements of care and a certain form of justice, dike.

\section{An Ethotic Dwelling}

It would be inconsistent, even hubristic, to imply that Heidegger was interested in sketching a sort of democratic ethic. Yet, it would be equally improvident to overlook the fact that his concerns echo the effort of those who live in "destitute times" to forge meaningful possibilities of co-existence.8 If Heidegger with his Letter on Humanism intended to discuss the meaningfulness of talking about humanism in such times, and to give some remarks on what it means to think hard on human affairs, then today his inquiries prove equally relevant as in the era of the Nuremberg Trials. For Heidegger not only urges us to grasp ethos as the mode of existence that is characterized by care for a complex world in constant flux, but also invokes thinking on the given order and its challenges. However, merely reflecting on the given order and demonstrating care for it is not enough. A life in common, a political life which is organized around democratic principles, is one that is infused with a logic of justice. 
The experience of injustice as well as the effort to transform it into justice, are constitutive moments of political life. As Wolin puts it, they serve "as moments for the demos to think, to reflect, per chance, to construct themselves as actors" $(1996,106)$. I find that a disposition such as the one argued for here forges such an encounter with in/justice and can, therefore, be a productive force in demotic life. However, justice is not here to be attributed the meaning of "justice as fairness," a justice that is the result of "reflective equilibrium" or accepted from an "original position;" neither is it a "distributive justice," in the sense of equal shares for all if interests compete. It is in the ancient Greek concept of dike that the content of justice that I am looking for here is to be found. My task, then, is to demonstrate how this particular form of justice infuses our comportment to the problem of scarcity and urges us to forge a more just, that is less uneven and imbalanced re-arrangement of things in public life.

The ethos that I argue for here, affirmed as a mode of dwelling in the world, is a political ethic formulated not as a set of principles of conduct but as a way of relating to the world; at the same time it is also a way of understanding our role within it, especially in relation to the world's other components. To say that our engagement with the exigencies of the world is infused by an ethos-as-dwelling is to suggest that our responses to daily encounters, or lack thereof, is indicative of the way we perceive and occupy the open region we live in; it is indicative of our care for the world. To place ourselves towards problems of injustice or scarcity is to think of the current state of affairs with the mood to re-arrange it; it is to inhabit the world in a political way.

The idea of ethos-as-dwelling as formulated in this article is permeated by the idea that humanitas, the essence of being human, entails being in the world politically. We are human and not inhuman (and not non-human) insofar as we show care for the world, human and non-human, by seeking to preserve and spare it; in other words by dwelling in it. A clarification on the role of preservation in this formulation would be useful. To say that dwelling entails the preservation of the world does not necessarily mean an emphasis on commitment to the current state of affairs. 
Occasionally, though, $a$ particular state might need to be preserved, as in the case of a set of work rights. Change and transformation are not to be uncritically associated with desirable and positive results, at least not for all. For the Romans the homo humanus was contrasted to the homo barbarus on the basis of honoring Roman virtus through the embodiment of the paideia (education) taken over from the Greeks (Heidegger 1977b, 224). For late moderns, humanitas can be interpreted as the mode of existence that engages with the world in order to pursue a more just formulation of the scheme of things. This re-formulation might include the preservation of an already just given order, as for example in the case of human or labor rights; but it also might include the struggle to forge a less uneven state of affairs between human and non-human environments, the fight against the intensive exploitation of exhaustible natural resources such as fossil fuels, as well as the effort to cultivate alternative visions of human progress that challenge the devastating obsession with growth.

The world of ancient Greek tragedies illuminates this fusion of justice and humanism. In this world, the man who exceeds his measure commits hubris and is punished by the Erinyes; justice is the norm in this universe of "pity and fear" (Aristotle 1968, 10). But in this very same universe, humanism is also a prevalent motif. Oedipus destroys the monster that devoured those who could not answer its riddle by using a single word: man. It is to man that we need to turn in order to destroy the monsters "in our gradually shrinking world" (Seferis 1963). Man is part of the problem of the shrinking world, not its victim; but at the same time, he is also part of the solution to this problem.

The concept of dike extends this logic of "making justice to avoid hubris" to the world of human reality. To demonstrate dike is to honor balance, to not overstep the bounds. It is, then, to be less arrogant and more attuned to the actual limits — or resources—one is allowed to. To be with other human beings - to be miteinander - in a way that does not invoke hubris, is bound up with justice. Humanitas, the essence of being human, is to dwell in the world just. Today we tend to 
equate dike to legal settlement, or attribute it a moral significance, by understanding it as fairness. Justice is, indeed, an ambivalent term. In Nicomachean Ethics, Aristotle interprets dike as balance, as proportion. After all, the tool that he, or Hesiod, would have used to measure what was fair and just, is a balance. To reinforce justice, or dike, is to avoid disaster by finding recourse to balance (Rodgers 1971).

The sophist Protagoras further illuminates our understaning of this term. When in his "Great Speech" he pairs dike with aidos as the two foundational elements of any political society, Protagoras offers an open-ended interpretation of justice (Plato 2009, 40). In doing so, Protagoras follows the prevailing in his era association of justice with balance, a norm that extends from nature to human societies.9 Dike is not dependent on established laws and legal settlements; its meaning flows from the symbol with which we identify it even today: balance. To pursue dike is to pertain to balance. In this sense, dike is situational justice; not justice that is already in place, in the form of laws, contracts, and principles, but one that remains open to be defined and re-appropriated. Hence it does not necessarily aim at the preservation of the existing order, neither is it committed to change merely in the name of it.

One of the virtues of bringing the concept dike in the discussion for a democratic ethos is that it helps us to tune in a less violent response to the problem of scarcity in "destitute times." To consider and aspire to dike is to not exceed the bounds, it is to seek to avoid hubris. We are dwellers not merely because we live on earth, under the sky as mortals who hold certain values. Rather, we are dwellers because we are infused with an ethos-as-dwelling, because we remain responsive to the limits that the biosphere imposes on us and we seek to spare it. Today, sparing the biosphere is not merely about preserving it, it is about starting to think about how the established state of affairs is out of bounds - it is to start seeking to forge a different, more just arrangement of our relation to the biosphere and its components. 
The biosphere - the complex of living things and the atmosphere, oceans, and soilscomprises an interactive, self-regulating system (Schwartzman 1999). But we have mistaken its self-regulating capacity for inexhaustibility; hence today we find ourselves amidst the paradox where we appear to be rich in means and poor in resources. But resources such as energy, but also money, time, even enthusiasm, are finite, as the sociologist Howard S. Becker observes (Becker $2013,378)$. Heidegger's advance of sparing as the trait that distinguishes human dwelling, as the attribute that infuses one's èthos, is inspiring today not least because it urges us to think and act while bearing in mind the limitations posed on us by our economic, natural, social and cultural environments. It also urges us to do so while considering our responsibility to proceed in a way that does not break with our humanitas. We are dwellers because we struggle against scarcity and we respond to the urgency to deal with scarcity while remaining human - that is while aspiring to a form of justice that will end the hubris we commit against the biosphere.

The formulation of èthos-as-dwelling crafted here does not stand antagonistically to other democratic dispositions or ethea. It could even be argued that it is better affirmed as plural in itself, as dwellings, as diverse ways in which individuals place themselves towards and in the world. As dwellers we remain receptive to what arrives to our abode and vigilant to occurrences that surround us in order to respond to them, to take care of them. We do not merely exist on earth under the sky, before the divinities, among mortals; we do so while we "stay with things" (Heidegger 1971, 141). To stay with things, to show concern for things, to let things be: Heidegger shows a way for engaging the world not in order to master it, but to inhabit it with care for what is and what will be. We "let things be" by not approaching them with exploitation in mind, that is by not attributing a particular value to them. To do so is to refuse to measure things for some usefulness they can have for us, and hence by taking them as things in their own value, in their own use.

But, we should add, our staying with things entails at the same time the attitude to challenge established allocations of roles, priorities or use of means. To dwell in the world democratically is, 
among other things, to be involved in the ongoing struggle for a more just, that is less uneven and more balanced, distribution of scarce resources.

\section{Conclusion}

This essay has argued that Heidegger is a productive contribution to the literature on democratic ethos. His remarks on the topic helped me to show how we can transcend the fixity of the original meaning of the concept instead of abandoning it altogether, by understanding ethos as action, as dwelling. I suggested that etthos-as-dwelling is a political ethic, not least because it refers to how one dwells on what is in common, to the experience of taking care of the common affairs. Moreover, it is an èthos that remains open, fleeting and therefore always relevant to the current conditions, with a provision for those yet to come. It specifically has a democratic quality because it corresponds to the ambiguity and indeterminacy that democracy entails due to its constant call for active explication of support to causes, responses to crises, and generous engagement with alterity. Despite its topological connotations, then, etthos-as-dwelling has a temporal aspect as well. A democratic ethos is one that is to be found in the intersection of place and time, of here and now. As such, it corresponds to the openness and indeterminacy of democracy, elements inherent to it, as Derrida puts it $(2005,25)$.

A democratic ethos has no definitive components: it remains relevant to the specificity of circumstances. It may be an èthos of generosity, as the work of Connolly suggests, and so an ethos that enables a more forbearing living between constituencies that honor diverse ethical sources. But it may also be an ethos that informs our responses to challenges posed by "those bodies and subjects for whom such a generosity is difficult, if not impossible," without this difficulty or impossibility entailing that these bodies are not democratic subjects (Lloyd 2010, 125). The openness of ethos that I advocate here, therefore, is an openness affirmed also as vigilance. To "let things be" is to 
take care of things, to treat them, to not let them go unchallenged, while remaining alert to what is to-come. This is an attitude that much sustains democratic life, not only by fueling responses to existing exigencies, but also by welcoming emerging disruptions of the familiar, of the everyday.

The ethic of care and dike that I advocate here advances the idea that being politically is an essential aspect of humanitas. To be human (that is, not inhuman, barbarian) is to care for, but also critically reflect on, human affairs. To dwell in the common world is to preserve and care for human affairs; it is also to dwell on these affairs towards a more just re-arrangement of the scheme of things, present and to come. Late modern man is a homo politicus in so far as he is a dweller in and on the world affairs.

\section{ACKNOWLEGMENTS}

The author would like to thank the anonymous reviewers for their constructive comments, as well as Samuel Chambers, Alan Finlayson, and James Martin for reading and commenting on earlier drafts of this essay.

\section{END NOTES}

